\title{
Actinobaculum schaalii
}

National Cancer Institute

\section{Source}

National Cancer Institute. Actinobaculum schaalii. NCI Thesaurus. Code C119311.

A species of facultatively anaerobic, Gram-positive, catalase-neg ative, nonmotile, nonspore forming, non-acid fast, nonhemolytic, straight to curved rod-shaped bacteria, in the phylum Actinobacteria. This species ferments glucose and produces acetate, succinate and acid; hydrolyzes hippurate, but does not reduce nitrate to nitrite; and does not hydrolyze esculin, gelatin or urea. A. schaalii is a part of the commensal flora of the human genitourinary tract and may cause urinary tract infections, urosepsis, bacteremia, cellulitis, spondylodiscitis, and endocarditis in humans. 